\title{
Evaluation of the impact of shiftwork and chronotype on the workers of the imprint and cutting/welding sectors of a flexible packaging manufacturer
}

\author{
L. B. de M. Guimarães ${ }^{\mathrm{a}^{*}}$, S.L.R. Pessa ${ }^{\mathrm{b}}$ and C. Biguelini ${ }^{\mathrm{a}}$ \\ ${ }^{a c}$ Graduate Program in Industrial Engineering, Federal University of Rio Grande do Sul, Av. Osvaldo Aranha 99 \\ $5^{\circ}$ andar, Porto Alegre, RS, 90035-190, Brazil \\ ${ }^{b}$ Department of Mechanical Engineering, Federal Technological University of Paraná, Via do Conhecimento, $\mathrm{km}$ \\ 1, Pato Branco, PR, 85503-390, Brazil
}

\begin{abstract}
This article presents a study on the impact of shiftwork and chronotype on the perception of the work conditions, workload and adjustment to shiftwork by the workers of two sectors of a flexible packaging manufacturer, which operates in three fixed shifts. The workers are allocated in one of the shifts (morning, evening and night shifts) without evaluation of their chronotype and/or social needs. The workers' evaluation of the shift system and their work show that they prefer a fixed shift and to work in a shift compatible with their chronotype. The workers with chonotype uncompatible with the shift time tend to be less satisfied with the work conditions and content and feel more discomfort/pain.
\end{abstract}

Keywords: job satisfaction, workload, subjective tools, physiological parameters.

\section{Introduction}

Night and shiftwork are getting more usual in many sectors. In the industrial one, they are being used to cope with the increasing demand and also as a means of maximizing the use of the facilities. However, these forms of work organization have been considered as one of the most contradictory in relation to individual and collective interests [58].

Shiftwork is any type of work carried out during unusual hours, during evening or night, to attend production needs, but it has serious impact on human being health and safety [e.g., 1,3-5,15-17,24-25,27$28,30,49-51,54-55,60]$. Therefore, some studies focus on adaptation to shiftwork $[1,9,62]$ and individual differences related to this adaptation $[5,18,23]$ and workers efficiency $[24,25,49,55]$. Other studies focused on the flexibility of shiftwork organization
$[17,31,32,45,46,56]$, the attributes of work schedules for special workers $[39,68]$ as well as autoschedule [10,69].

A practical study at an iron metallurgy plant in the Netherlands [43] compared the change of anticlockwise shiftwork to a fast clockwise system. After six months, the results were less fatigue and better sleeping patterns. The older workers ( $>50$ years old) benefit more in terms of sleep quality, maybe because they sleep during the days off while the younger ones use their time off for other activities. Klein et al. [43] emphasize the importance of worker participation in changing the shiftwork system (which lasted almost 25 years) in such a large company (4600 people working in shift and 1450 workers during the day).

In developing countries, a study in a shoe component manufacturer in Bangladesh [3], with shiftwork

\footnotetext{
*Corresponding author. Email: liabmg@gmail.com
} tel: +55 51 3308-3948 fax: +55 51 3308-4007 
changing every week, showed that $76 \%$ of the workers did not like the schedule, $3 \%$ reporting that it imposes potential life risk. $83 \%$ reported health problems, $85 \%$ sleep problems and $78 \%$ irregular meal times. $57 \%$ like the job, the salary, benefits (i.e. leave of absence for religious practices), and the relationship with managers and supervisors. Ahasan et al. [2] stress that in Bangladesh the labor unions are often more concern about their own goals than to solve problems related to shiftwork (that is not clear in the country's policies) and working conditions. Religious practices tend to reduce work dissatisfaction, increase safety and productivity, but shiftwork disrupts these practices.

The literature states that there is not a best shiftwork system because each one has physical, psychological and social advantages and disadvantages [62]. It is difficult or even utopic to establish an ideal schedule because many variables are mixed such as continuous, semi-continuous or discontinuous work, team size, fixed or alternating teams, direction and duration of rotation, free time, early retirement etc. Clockwise rotation favors a better distribution of free time, but anti-clockwise rotation implies more free time; fast rotation avoids fatigue accumulation but disrupts the socio-familiar relationship [72]. Wilkinson [76] conclude that fixed shifts were better in many aspects but Wedderburn [75] disagrees because fast rotation has more advantages. Some workers prefer schedules considered unsatisfactory, as the 12 hours shift, seven consecutive night shiftwork working weeks instead of six with a lower wage [72]. The reason is that they look for reconciling health, work restrictions, familiar and social relationship and their values (economical, moral, religious, and political). Moors [56] found that the time of the journey impacts on fatigue in the same extent as long journeys.

In summary, most authors understand that a fast rotation clockwise alternating shift is less psychophysically demanding than a fixed system [70] although improvements in quality of life (good alimentation, housing, transportation and social services) has a positive impact on how the worker deals with shiftwork since it compensates for this stressful work condition [16]. Recommendations for night and shiftwork $[14,30,41,45,46,48,59,66]$ are: reduce the number of consecutive nightshifts to a maximum of three $[28,48]$ to minimize physiological, circadian problems, and accumulation of sleep deficit [48]; avoid anti-clockwise rotation with the first week of five nights followed by one week of evening work and of one week of day work $[42,48,71]$; best option is a fast forward clockwise system with only two consecutive shifts of the same type; a minimum of two free days after the last nightshift; no free time between nightshifts; avoid isolated work between free time. Despite the recommendation of clockwise shift, some authors question the positive effects of this system $[4,28,66]$, and the workers tend to prefer the anti-clockwise system due to the extra free day they get [47]. Other recommendations are: start the shift later in the morning (at 7:00 AM instead of 6:00 $\mathrm{AM}$ ) to minimize sleep disturbance; end the evening shift at 10:00 PM instead of 11:00 PM [48]; leave a minimum of two consecutive days free weekends; allow a minimum of 11 hours between two shifts; allow a maximum of five to seven consecutive shifts; avoid extended shifts (i.e., 48 hours shifts); adjust the worker to shiftwork [48]. In general, the circadian clock adjusts to the nightshift in less than one week [44]; allow flexible working schedules, what is possible under autonomous groups work design.

The European Foundation for the Improvement of Living and Working Conditions [74] recommends: a reduction of night shifts dose; a limit of two to four fixed nightshifts; fast forward rotation of one to three journeys; start the morning shift not too early; free time between shifts not inferior to 11 hours; implementation of 12 hours shift only when the type of work and workload are adequate to long journeys; adoption of flexible schedules, including journeys with variable duration and personalized working hours. The Brazilian Labor Law 5.452 Article 66 [12] regulates that between two consecutive shifts there will be a minimum of 11 hours of time off to compensate for biological stress and social deprivation, besides the negative impacts of shiftwork and increase in accidents rate [27].

Night work is appropriate if: the workers are trained so their circadian cycle adjust previous to the change of shift; the night shift workers had previous experience with the night shift and has no sleep deprivation; in the selection for night shift, volunteerism and other incentives are considered [6].

Night and shiftwork generates health problems but the majority of studies do not consider the social $[21,47,61]$ and individual factors involved in the tolerance to unusual schedules $[9,15,67,74,76]$. Knauth [47] points out that the needs and wants of human beings are not constant during life since they depend on the phases of life. For example, they depend on the need to study (mainly in the case of the younger workers), whether there are children in the family and of the age of the children (mainly in the case of women); worker's age and production 
capacity. Besides, the way night and shiftwork are organized (i.e., a schedules, journey hours, resting pauses [16] and the workers strategies to reconcile their lives with work [61] are fundamental for evaluating tolerance to unusual working hours.

The most important individual factors impacting on the tolerance to night and shiftwork are age, gender, physical fitness and personality [16]. Older people show progressive intolerance that might be related to lower physical fitness, less sources for sleep restoration, and tendency to desynchronization of the circadian rhythm $[7,38,43,64,65]$. Although most studies on night and shiftwork focus on men [61], women have difficulties in reconciling work and family [51]. Some studies show that nurses tend to choose a fixed night shift, often due to familiar matters, what impacts on the better adaptation to the shift [9]. Night work is a motivation factor for women because they can reconcile family and work $[13,50,53,60,63,73]$ a situation that despite the overload due to the double task is compensated by the children presence.

Considering personality, people with high level of neuroticism or rigid sleep habits and less capacity to overcome sleepiness show more difficulty in adapting to irregular work schedules [16]. Moreno [57] concluded that electricians better adapted to alternating shiftwork were those with lower stability between the sleep/vigilance cycle and temperature rhythm, since this flexibility allowed them to sleep in different hours and get more rest. 15 to $20 \%$ of the workers cannot cope with night and shiftwork while 5 a $10 \%$ do not show any adverse out-come, what leads to the "healthy worker" effect (i.e. stays in the shiftwork only the ones who can cope with it [16]). Extreme chronotypes (the human beings tendency to morningness/eveningness) have more difficulty to adapt to a shift contrary to their circadian cycle [16]. Morning people express their circadian rhythm earlier in the day in comparison to night people. Fischer [22] found that morning people prefer to start work at 7:00 AM while night people prefer to start at 12:00 PM. The majority of the population, however, has moderate habits of morningness/eveningness; therefore people should also choose their working hours according to their chronotype [47].

Few studies that evaluated the perception of workers considering their chronotype in a mailing company [8], in a call center [19], in a steel metallurgy [34] and in a oil transportation company [52] showed that people working in shifts not compatible with their chronotype felt more stress and less satisfaction with the work conditions. The majority of workers prefer fixed shift schedules instead of the rotating one, due to the possibility to better organize their social lives. Chronotype was the most important variable in defining the preferred working shift but there were cases where social factors (caring for the children, studying etc) led them choose another shift. In those cases, work satisfaction was not affected because other needs were satisfied by the chosen shiftwork. In all studies, the benefit of $20 \%$ additional salary [12] for night shift was another factor for choosing the night shift. In the oil transportation company [52], all drivers were morning type and did not like to work night shifts. Other study [11] evaluated health conditions, sleep quality, satisfaction with time off, and ergonomic demand items of the workers in an Imprint sector of a graphics industry operating in three fixed shifts. Chronotype had no influence on the results, the night shift showing to be less tolerated, with the worst results for all evaluated variables. The workers like the fixed shift schedule but a general complain was the amount of free time, for all workers from the three shifts.

Chronotype is one of the individual differences that if not considered in work design might lead to stress, frustration and low performance, i.e., human suffering and negative impact on production. The literature on night and shiftwork comment on the problems of night shift but there is no evidence on the benefits of allocating people according to their chronotype. Verdier et al. [72] and Knauth [47] consider that if the companies want to be more flexible and improve worker's motivation, they have to start to delegate more responsibility to the workers, give them more autonomy for organizing their working schedule and choose the journey model.

In order to contribute to the night and shiftwork literature, this study evaluated the impact of chronotype and shiftwork on the perception of the work performed by 85 employees from 2 sectors of a packing manufacturer company, which operates in three fixed shifts. Another article presents the physiological and subjective workload evaluation by these same workers.

\section{Method}

Forty two workers from the three shifts of the Imprint (I) sector and 43 workers from the Cutting/Welding (CW) sector were characterized according to gender, professional experience, age and 
chronotype. Chronotype was evaluated based on two questionnaires: the Horne and Osberg $(\mathrm{H} / \mathrm{O})$ nineteen questions questionnaire to determine morningness/ eveningness in human circadian rhythms [40] and the Guimarães self-evaluation questionnaire based on four questions [35] plus four questions about the preferred working hours (and the non-preferred), the time the workers fell more vigilat (and less vigilant).

Work analysis was done following the participative method Macroergonomic Work analysis (MA) [33] that uses both the workers and ergonomists' evaluation about the environment, the workstation, the work organization and the Company as well as the work content, and the level of pain/discomfort based on the first three stages of the Macroergonomic Design technique (DM) [29,37]; 1) the identification of the ergonomic demand items (EDIs) by open interviews (qualitative) with a sample of the population (in general 30\%); 2) prioritizing the most important EDIs; and 3) incorporating the ergonomists opinion to build a questionnarire to be answered by the whole population. The opinion of each employee with respect to EDI is measured by means of a mark on a $15 \mathrm{~cm}$ long continuous assessment scale [67]. The questionnaires allowed the perception of the participants to be measured quantitatively and the results to be statiscally analysed. The workers also answered an adapted NASA TLX questionnaire [36] to evaluate workload. Quetionnaires showed good internal consistency by Cronbach's alpha statistics [20], but did not show normality by Kolmogorov-Smirnov test. Therefore, the results were analyzed by descriptive statistics and non-parametric statistical. The Kruskal-Wallis test was used to compare the responses as a function of the type of respondent, such as gender, age, experience and chronotype. Workers with chronotype compatible with the shift are denominated CC workrs and workers in shifts uncompatible with their chronotipe were denominated UC workers. The results with a statistical difference (significant to $\mathrm{p}$ value $<0.10$ ) were analyzed with a non-parametric comparison test. The Mann Whitney U test was used to compare the answers from two groups. Fisher's exact test was used to evaluate correlation between the $\mathrm{H} / \mathrm{O}$ and the Guimarães questionnaires. Spearman's rank correlation coefficient test was used to measure statistical dependence between two variables, and Wilcoxon difference test was used to compare paired data. The $90 \%$ confidence level was considered instead of the usual $95 \%$, due to the small number of workers (85) in the sample.

\section{Results}

\subsection{Characteristics of the sample}

The research sample is composed by 85 workers (mean age 27 years old): 42 male workers from the three shifts of the I sector and 43 (39 being women) from the CW sector of the Company. Twenty-four people $(28.2 \%)$ work in a shift incompatible with their chronotype, according either to the $\mathrm{H} / \mathrm{O}$ or the Guimarães questionnaire.

Fisher's exact test showed significant correlation between the $\mathrm{H} / \mathrm{O}$ classification and the Guimarães self-chronotype classification in both the $I(p=0.039)$ and CW $(\mathrm{p}<0.001)$ sectors. There is also correlation between $\mathrm{H} / \mathrm{O}$ classification and $\mathrm{H} / \mathrm{O}$ selfclassification (question 19 of $\mathrm{H} / \mathrm{O}$ questionnaire) both in the $\mathrm{I}(\mathrm{p}<0.001)$ and in the CW $(\mathrm{p}<0.001)$ sectors, and between the Guimarães and $\mathrm{H} / \mathrm{O}$ selfclassifications also both in the $I(p=0.066)$ and the CW ( $p=0.009)$ sectors. Significant association between the two questionnaires $(p<0.001)$ was also found by $[19,52]$. Therefore, in the case a company agrees to consider chronotype as one of the factors for designing a shiftwork schedule, and if it considers difficult to use the $\mathrm{H} / \mathrm{O}$ questionnaire, chronotype can be accessed by self-evaluation.

\subsection{Workers' opinion about the shiftwork schedule}

The questionnaire about the satisfaction with the shiftwork and best/worst time for working schedule showed that $47(55.3 \%)$ out of the 85 workers do not like shiftwork, $13(15.3 \%)$ are indifferent and 25 $(29.4 \%)$ like shiftwork, as long the system is fixed. $76(89.5 \%)$ said that if shiftwork is necessary the best system is the fixed one, only $9(10.5 \%)$ preferring the rotating shift. The results are in agreement with $[3,8,9,34,52,76]$ but diverge from the proposal of researches [70,74] who understand that the better system is the clockwise, fast forward alternating one instead of the fixed shift.

Wilcoxon test showed that morning workers want to start the journey around 6:00 AM and end around 11:30 AM. The workers with chronotype tending to morningness want to start around 7:40 AM and end around 1:00 PM. The workers with cronotype tending to eveningness want to start the journey around 4:00 PM and end around 12:00 AM. The evening type workers want to start around 5:45 PM and end around 6:15 AM. The Mann-Whitney U test showed statistic difference $(p=0.091)$ for the 
preferred hour for starting the journey in shift 1 of the I sector: CC workers want to start around 8:00 AM while UC workers around 10:00 AM. The result was expected since people with evening habits start their activities later in the day.

Spearman's test showed that both in the I $(\mathrm{p}<0.001)$ and $\mathrm{CW}$ sector $(\mathrm{p}<0.001)$ there is positive correlation between the time chosen to start the journey and the time the workers feel more alert; and negative correlation $(p=0.019$ in the I sector between the time chosen to start the journey and the time the workers feel less alert. As expected, there is negative correlation $(p=0.020)$ between the time workers feel more alert and the time they feel less alert to start the journey. There is positive correlation $(p<0.001$ in the I and $\mathrm{p}<0.001$ in the $\mathrm{CW}$ sector) between the time chosen to end the journey and the time they feel more alert to end, as well as negative correlation $(\mathrm{p}=0.028$ in the I sector) between the time they feel more alert and the time they feel less alert to end the journey. Eighty seven percent of the workers in the two sectors consider that sleepness is related to higher risk at work.

\subsection{Shift and perception of the work}

\subsubsection{Imprint sector}

The I sector is characterized by moderate to high physical and mental efforts, monotony above average and limitation bellow average. The work is considered criative, dinamic and estimulanting, but very repetitive despite task diversification is above average Work envolves high responsibility, psicological pressure being above average what explains the nervousism also above average. They feel valued by the Company, have autonomy and like their work.

The Kruskal-Wallis test showed statistic difference among shifts in the I sector for satisfaction with the temperature $(p=0.003)$ and noise $(p=0.017)$. Shift 1 is more unsatisfied with the temperature than shifts 2 and 3 although the three shifts have scores below average. Shift 2 is the least unsatisfyed with noise while shift 1 is the most unsatisfied. The result was expected since shift 1 has more movement and people, resulting in more noise. There are also statistic difference among the EDIs overall relationship at shop floor $(\mathrm{p}=0.041)$, relationship with the supervisors $(p=0.077)$, work rhythm $(p=0.004)$ and task organization/distribution $(\mathrm{p}=0.006)$. Shift 2 presents higher level of satisfaction with these EDIs in comparison to shifts 1 and 3 . There is also statistic difference among the three shifts for the EDIs responsability $(\mathrm{p}=0.001)$, psychological pressure $(p=0.054)$ and like the work $(p=0.068)$ : responsibility is higher in shift 2, which is the shift that likes the work more despite feeling more psychological pressure. In the NASA-TLX, the Kruskal-Wallis test showed that shift 1 has higher physical demand $(p=0.007)$, effort $(p=0.019)$ and total demand $(p=0.075)$ in comparison to shifts 2 and 3 .

The intensity of pain is high in the back and feet what is expected considering the heavy material handling (bobbins and axis) the work being done always in a standing uo position. The Kruskall Wallis test did not show statistic difference in intensity of pain among the shifts in any part of the body.

\subsubsection{Cutting/Welding sector}

The workers from the CW sector consider that the work involves physical and mental efforts above average, monotony and limitation are below average, creativity and dinamism are in the average, and the tasks are very repetitive and little diversifyed. Despite that, the work is considered stimulating. Psichological pressure is below average as well as nervousism. They feel valued by the Company, have autonomy, like the work which involves high responsibility. There is significant difference among the mean satisfaction of the three shifts with the temperature $(p=0.0785)$, task distribution $(p=0.010)$ and oportunity of promotion $(\mathrm{p}=0.0183)$, the shift 2 being more satisfyed than shifts 1 and 3 . In the three shifts, the pain is high in the legs and feet what is consistent with the long term static, standing up position adopted. The Kruskall Wallis test did not show statistic difference in intensity of pain among the shifts in any part of the body.

\subsection{Chronotype, shift and satisfaction with the work}

Although the literature comments on the effect of age, experience and gender on the tolerance to shiftwork, there was no workers older than 50 years, or workers with more than 13 years of experience. Gender effect could not also be evaluated because the I sector was composed only by men and the CW sector had 39 women and only 4 men performing different tasks. Therefore, only the effect of chronotype on the satisfaction of shiftwork was evaluated. The Mann-Whitney U test comparing UC and $\mathrm{CC}$ workers in each shift of the two sectors show the following statistic differences: 
In the I sector: in shift $1, \mathrm{CC}$ workers prefer to start the work earlier $(\mathrm{p}=0.091)$. In shift 2 , although satisfaction is above average, $\mathrm{CC}$ workers are less satisfied with the the quality of the tools $(p=0.018)$, the adopted posture $(p=0.01)$, general relacionship at shop floor $(\mathrm{p}=0.062)$ and relacionship with supervisors $(\mathrm{p}=0.072)$. UC workers feel more mental effort $(p=0.022)$ what makes sense since morning people tending to morningness have to put more effort to compensate for the biological dessincronization between the time they are more vigilant (in the morning) and the shift (which is in the evening). In shift 3, although the level of satisfaction is high, CC workers are less satisfied with the work pannel $(p=0.043)$ and feel more mental effort $(p=0.045)$. UC workers are very unsatisfied with extra hours $(\mathrm{p}=0.045)$ and opportunity for prommotion $(\mathrm{p}=0.064)$ and $\mathrm{CC}$ workers are satisfied, and they do not feel the work as stimulating as it is for CC workers $(p=0.005)$. There is statistic difference between $\mathrm{CC}$ and $\mathrm{UC}$ in shifts 2 and 3 in relation to menal demand $(p=0.0139)$ and total demand $(\mathrm{p}=0.0138)$ of the NASA- TLX which is higher for morning type workers. There is also difference between the pain perceived by $\mathrm{CC}$ and UC workers in the arms $(p=0.0832)$, legs $(p=0.0181)$, feet $(\mathrm{p}=0.0641)$ and back $(\mathrm{p}=0.0668)$ which are higher for UC workers in shift 1; and in the arms (0.02517), back $(\mathrm{p}=0.02517)$ and neck $(\mathrm{p}=0.0652)$. which are higher for UC workers in shifts 2 and 3.

In the $\mathrm{CW}$ sector, there is statistic difference in the feeling of pain between CC and UC workers in shift 1 , the latter feeling more pain in the feet $(p=0.0516)$, arms $\quad(p=0.0505)$, legs $\quad(p=0.0234)$ and feet $(\mathrm{p}=0.0480)$. In shift $2, \mathrm{CC}$ workers consider their work more repetitive than UC workers $(\mathrm{p}=0.087)$. In shift 3, UC workers feel their task more stimulating $(p=0.033)$ and feel more valued $(p=0.038)$ than $C C$ workers, but UC workers feel more total demand $(\mathrm{p}=$ 0.06) in the NASA-TLX.

The results show that, in general, shift 2 in the two sectors is more adapted to the work conditions. Shift 1 has more demand for production mainly in the I sector, since production for large batches is done in shift 1 . This results in the higher physical demand, effort and psychological pressure in shift 1 . The impact factor on shifts 3 of both sectors can be explained by the time of the shift, since night shift is usually the one that generates more complaints [11, $21,26]$. The level of impact of the uncompatibility between chronotype and shift depends on the sector (i.e., the type of work, work organization and content) since there is difference between sectors: in the I sector, the morning or tending to morningness workers (all male) showed more difficulty in coping with the evening or night shifts. In the CW sector, the tending to eveningness or evening type workers showed more difficulty in coping with the day shift, what is in agreement with Costa [16]. It is important to note that in the $\mathrm{CW}$ sector the majority is women, therefore gender might have had an effect on the intolerance, in respect with the disruption with the familiar contact, corroborating [13,50,53,60,63,73].

Corroborating Knauth [47], the results points in the dierction of the possibility of letting people choose the shift according to their chronotype, besides other social and familiar needs. Considering that people are not machines, their performance varying during the journey and that their needs changing as a function of the stages of life [47], the better work schedule is the flexible one.

\section{Conclusion}

The study made clear that the morning shift is the most demanding one and the evening shift is the most tolerated. The most important finding is related to workers' chronotype and their adaptation to shiftwork. The workers with chonotype uncompatible with the shift time tend to feel more effort, discomfort/pain The workers know their best work time, which is compatible with their chronotype, therefore there is no reason for designing a shift schedule without considering this individual characteristic. However, because people's needs and wants vary during life, a proposition is to design a participative work schedule, adjusting the chronobiological, social and familiar needs. Scheduling could be set by groups, as in the autoscheduling system, where workers influence the shifts design but also define their working hours inside the shift schedule.

\section{References}

[1] M.R Ahasan, Human adaptation to shift work in improving health, safety and productivity: some recommendations. Work Study 51 (1) (2002), 9-16.

[2] M. R. Ahasan, D. Campbel, A. Salmoni and J. Lewko, Some intervening and local factors among shift workers in a developing country - Bangladesh, J Workplace Learning 13 (4) (2001), $164-171$.

[3] M.R. Ahasan, G Mohiuddin and A. Khaleque, Psychosocial implications of shift work: a case study, Work Study 51 (3) (2002), 116-120. 
[4] T. Akerstedt, Shift work and disturbed sleep/wakefulness, Occupational Medicine, 53 (2003), 89-94.

[5] T. Akerstedt and L. Trosvall, Shift work: shift dependent wellbeing and individual differences, Ergonomics 24 (1981), 265-73.

[6] E. E. Alves and C.M. Kelsey, Combating vigilance decrement in a single-operator radar platform, Ergonomics in Design, 18 (2) (2010), 6-9. Santa Monica: Human Factors and Ergonomics Society.

[7] A. Baker, G. Roach, S. Ferguson and D. Dawson, Shift work experience and the value of time, Ergonomics 47 (3) (2004), 307-317.

[8] J. R. Baratto, L. B. de M. Guimarães and Ä. M. O. Sant' Anna, Avaliação da carga de trabalho no tratamento de encomendas, in: L.B. de M Guimarães, org., Macroergonomia: aplicação em produtos e serviços, Cap. 4.2, p. 1- 35, 2010.

[9] J. Barton, Choosing to work at night: a moderating influence on individual tolerance to shiftwork, J. Appl. Psychology 79 (1994), 449-454.

[10]M. Beltzhoover, Self-scheduling: an innovative approach, Nurs Manage, 25 (1994), 81-82.

[11]P. C. B. Bento, Qualidade do sono, das relações sociais e da saúde, de acordo com a percepção dos trabalhadores em turno e noturno, Dissertação (Mestrado profissionalizante), Programa de Pós-graduação em Engenharia de Produção, Universidade Federal do Rio Grande do Sul, Porto Alegre, 2004.

[12] Brasil, Casa Civil da Presidência da República, 1988. Law n 5.452, from 1 May 1943, Aproves the Consolidation of Labo Laws, Available from www.planalto.gov.br/ccivil 03/decretolei/del5452.htm Accessed 15 July, 2011.

[13]D. Brown, Shiftwork, equality and women, J. Human Ecology 11 (1982), supl: 475-482.

[14] W.P. Colquhoun, G. Costa, S. Folkard and P. Knauth, Shift work: problems and solutions, Frankfurt, Peter Lang, 1996.

[15]G. Costa, The impact of shift and night work on health, Appl. Ergon 27(1) (1996), 9-16.

[16]G. Costa, Saúde e trabalho em turnos e noturno, in: F.M. Fischer, C.R.C. Moreno, L. Rotemberg, (eds) Trabalho em turnos e noturno, São Paulo, Atheneu, 2004, p.79-98.

[17] G. Costa, T. Akersted, F. Nachreiner, F. Baltieri, J. Carvalhais, S. Folkard, M.F. Dresen, C. Gadbois, J. Gartner, H.G. Sukalo, M. Harma, I. Kandolin, S. Sartori and J. Silverio, Flexible working hours, health, and well-being in Europe: Some considerations from a SALTSA project, Chronobiol. Int., 21 (2004), 831-844.

[18]G. Costa, G. Lievore, G. Casaletti, E. Gaffuri and S. Folkard, Circadian characteristics influencing individual differences in tolerances and adjustment to shift work, Ergonomics 32 (1989), 373-85.

[19] S.M. Couto, A influência da matutinidade/vespertinidade na suscetibilidade das demandas ergonômicas em operadores de teleatendimento que trabalham em turnos, Dissertação (Mestrado profissionalizante), Programa de Pós-graduação em Engenharia de Produção, Universidade Federal do Rio Grande do Sul, Porto Alegre, 2003.

[20]L. J. Cronbach, Coefficient alpha and the internal structure of tests, R Psychometrika 16 (1951), 297-334.

[21]F. M. Fischer, Condições de trabalho e de vida em trabalhadores do setor petroquímico, Tese de Livre-Docência, Faculdade de Saúde Pública da Universidade de São Paulo, 1990.

[22]F. M. Fischer, As demandas da sociedade atual, in: F.M. Fischer, C.R.C Moreno, L. Rotemberg, (eds), Trabalho em turnos e noturno, São Paulo, Atheneu, 2004(a), p.3-17.
[23]F. M. Fischer, Fatores individuais e condições de trabalho e de vida na tolerância ao trabalho em turnos, in: F.M Fischer, C.R.C. Moreno, L. Rotemberg, (eds) Trabalho em turnos e noturno, São Paulo, Atheneu, 2004(b), p.65-76.

[24]F.M. Fischer, A. Berwert, A.C. Bruni, C.R.C Moreno, R.L. Fernandez and C. A Riveielo, Organização do trabalho em turnos e repercursões no sono de trabalhadores petroquímicos, Rev Brasil Saúde Ocupacional 21(78) (1993), 33-41.

[25]F.M. Fischer, T.C. Morata, C. Zavariz, S. Colacioppo, E. Krieg, K. Wallingford, A.C. Fiorini, M.A. Padrão, Gozzoli, C. L. Galvão, G. Ventura, A. Montini and M. R. Latorre, Combined effects of environmental and organizational factors on health of shiftworkers of printing industry, XIII International Symposium on Night and Shiftworkers, Majvik, Finland, June, 1997(b).

[26]F. M. Fischer, C.R. De C. Moreno, F.N.S. Borges, F.M. Louzada, Implementation of 12 hour shifts in a Brazilian petrochemical plant: impact on sleep and alertness, Chronobilogy International, 17 (2000), 521-537,

[27]F. M. Fischer, J.C. Scatena and A. de C. Bruni, Effects of sleep and leisure time under continuous shiftwork schedules of subway workers, in: A. Ogisnki, J. Pokorski, J. E Rutenfranz, (eds), Contemporary advances in shiftwork research, Theoretical and practical aspects in the late eighties, Medical Academy, Krakow, 1987, pp. 375-384.

[28] A. Fletcher and D. Dawson, A quantitative model of workrelated fatigue: empirical evaluations. Ergonomics 44 (5) (2001), 475-488.

[29]F.S. Fogliatto and L. B. de M. Guimaraes, Design macroergonômico: uma proposta metodológica para projetos de produto, Produto \& Produção 3 (3) (1999), 1-15.

[30]S. Folkard and P. Tucker, Shift work, safety and productivity, Occupational Medicine 53 (2) (2003), 95-101.

[31]O. Gartner, D. Janßen, C. Schomann and F. Nachreiner, A new approach for evaluating flexible working hours, Chronobiol. int. 21:1015-1024, 2004(a).

[32] J. Gartner, S. Popkin, W. Leitner, S. Wahl, T. Akerstedt and S. Folkard, Analyzing irregular working hours: Lessons learned in the development of RAS 1.0 - The representation and analysis software, Chronobiol. Int. 21(2004(b), 1025-1035.

[33]L.B. de M. Guimarães, Ergonomic approach: the macroergonomic method. In: Guimarães L.B. de M. (org.) Ergonomics in Production. Porto Alegre: FEENG, fourth ed.v. 1. chap. 1.1.,1999.

[34]L. B. de M. Guimarães, Relatório de avaliação ergonômica em uma Aciaria do Rio Grande do Sul, 2003 (a). Não publicado.

[35]L. B. de M. Guimaraes, Questionário para Avaliação de Cronotipo. Porto Alegre, UFRGS/PPGEP, 2003(b).

[36]L. B. de M Guimarães and R. L. Diniz, Adaptation of the NASA-TLX questionnaire. First used in: Diniz, R.L. Avaliação das Demandas Física e Mental no Trabalho do Cirurgião em Procedimentos Eletivos, 2001. Tese de Doutorado Programa de Pós-Graduação em Engenharia de Produção UFRGS - Porto Alegre. 2003.

[37]L. B. de M. Guimarães and F.S. Fogliatto, Macroergonomic Design: a new methodology for ergonomic product design. in: IEA 2000 (International Ergonomics Association Conference), San Diego (California). Proceedings of IEA'2000 (International Ergonomics Association Conference) v. 2., (2000), p. 328 328.

[38]T. Hakola, M. Harma, Evaluation of a fastforward rotating shift schedule in the steel industry with a special focus on ageing and sleep, J Human Ergology 30 (1-2) (2001), 315-319.

[39]B.B. Hobbs and L.A. Farr, Assessing Internet survey data collection methods with ethnic nurse shift workers, Chronobiol. Int. 21 (2004), 1003-1013,. 
[40] J.A Horne and O. Ostberg, A self-assessment questionnaire to determine morningnesseveningnessnin human circadian rhythms. Int. J. Chronobiol. 4 (1976) 97-110.

[41]B. Jansen and K H. Kroon, Rota-risk-profile-analysis, Work \& Stress 9 (1995), 245-255.

[42]D. Jansen and F. Nachreiner, Differential psychological effects of different shift systems, A comparison of the effects of shift work under different systems in the chemical industry, Shift International News 18 (10), 2001.

[43] J. H. Klein, J. De Leede and A.Goudswaard, Effects of the new fast forward rotating five-shift roster at a Dutch steel company, Ergonomics 53 (6 ) (2010), 727-738.

[44]P. Knauth, The design of shift systems, Ergonomics 36 (1-3) (1993), 15-28.

[45]P. Knauth, Designing better shift systems, Appl Ergon 27 (1) (1996), Shiftwork Special Issue, 39-44.

[46]P. Knauth, Innovative working time arrangements, Scand J Work Environm Health 24 (3) (1998), 13-17.

[47]P. Knauth, Modelos e tendências de jornada de trabalho flexíveis em setores de produção e serviços: o caso da Europa, in: F.M. Fischer, C.R.C. Moreno, L. Rotemberg, eds, Trabalho em shifts e noshift, São Paulo, Atheneu, 2004, p.19-30.

[48]P. Knauth and S. Hornberger, Preventive and compensatory measures for shift workers, Occup Med 53 (2003), 109-116.

[49]A. Knutsson, Shiftwork and cardiovascular disease, National Institute for Psychosocial Factors and Health, Karolinska Institute, Stockoholm, 1989.

[50]K. Lee, Self-reported sleep disturbances in employed women, Sleep 15 (1992), 493-498.

[51]R.J. Loudon and P. Bohle, Work/non-work conflict and health in shiftwork: relationships with family status and social support, Int. J. Occup. Environ. Health 3 (2) (1997), S71-S77.

[52]B. G. Makowski, L.B. de M. Guimarães and L. Ballardin, Análise do cronotipo dos motoristas e alocação de turnos em uma transportadora de produtos perigosos, Anais ... ABERGO, 2006.

[53]G.M.S. Menezes, Trabalho noturno e saúde: um estudo com profissionais de enfermagem de um hospital público em salvador, Bahia, Dissertação de mestrado, Universidade da Bahia, Salvador, 1996.

[54]T. Monk and S. Folkard, Making shiftwork tolerable, Taylor \& Francis, 1992.

[55] T. Monk, S. Folkard and A. Wedderburn, Mantaining safety and high performance on shiftwork, Appl Ergonom 27 (1) (1996), Shiftwork Special Issue, p. 39-44.

[56] S.H. Moors, Learning from a system of seasonally determined flexibility: beginning work earlier increase tiredness as much as working longer days, in G. Costa et al. eds, Shift Work: Health, Sleep and Performance, Peter Lang, Frankfurt, pp. 310-15, 1989.

[57]C.R.C. Moreno, Critérios cronobiológicos na adaptação ao trabalho em turnos alternantes: validação de um instrumento de medida, São Paulo, 1993, Dissertação (Mestrado) Faculdade de Saúde Pública da Universidade de São Paulo.

[58]Y. Quéinnec, C. Teiger and G. de Terssac, Repères pour négocier le travail posté, 3e édition, Toulouse, Octarès Éditions, 2008.

[59]R.R. Rosa and M.J. Colliganl, Plain language about shiftwork, Washington, DC, US Department of Health and Human Services, National Institute for Occupational Safety and Health, 1997.

[60]L. Rotenberg, Trabalhando de noite e dormindo de dia: regularidade do sono e adaptação psicológica de operárias do turno noturno, Tese, São Paulo, 1997.

[61]L. Rotenberg, Medidas de intervenção: abordando a questão do lado dos trabalhadores, empresas e usuários, in: F.M.
Fischer, C.R.C. Moreno, L. Rotemberg, eds, Trabalho em turnos e noturno, São Paulo, Atheneu, 2004(a), p.53-63.

[62]L. Rotenberg, Aspectos sociais da tolerância ao trabalho em turnos, noturno, com ênfase na questões relacionadas ao gênero. in: F.M. Fischer, C.R.C. Moreno; L. Rotemberg, eds, Trabalho em turnos e noturno, São Paulo, Atheneu, 2004 (b), p.213-224.

[63] L. Rotenberg, L.F. Portela, W.B. Marcondes, C. Moreno and C.P. Nascimento, Gênero e trabalho noturno: sono, cotidiano e vivências de quem troca a noite pelo dia, Cad. Saúde Pública, 17 (2001), 639-649.

[64] I. Rouch, P. Wild, D. Ansiau and J.C. Marquie, Shift work experience, age and cognitive performance, Ergonomics 48 (10) (2005), 1282-1293.

[65]B. Ryan, J. R. Wilson, S. Sharples, F. Kenvyn and T. Clarke, Rail signallers' assessments of their satisfaction with different shift work systems, Ergonomics 51 (11) (2008), 1656-1671.

[66] M.B. Spencer, K.A. Robertson, S. Folkard, The development of a fatigue risk index for shiftworkers, Research report 446, Norwich, HSE Books, 2006.

[67]H. Stone, J. Sidel, S. Oliver, A. Woolsey and R.C. Singleton, Sensory evaluation by quantitative descriptive analysis, Food Technology, 28 (11) (1974), 24-34.

[68] L.R.Teixeira, F.M. Fischer, R. Nagai and S.L. Turte, Ten at work: The burden of a double shift on daily activities, Chronobiol. Int. 21 (2004), 845-858.

[69]L. Thornthwaite and P. Sheldon, Employee self-rostering for work-family balance, Leading examples in Austria, Employee Relations 26 (3) (2004), 238-254.

[70] P. Tucker and S.R. Knowles, Review of studies that have used the standard shiftwork index: evidence for the underlying model of shiftwork and health, Appl Ergonom 39 (2008), $550-564$

[71]L.G.P.M. van Amelsvoort; N.W.H Jansen, G.M.H. Swaen, P.A van den Brandt and I. Kant, Direction of shift rotation among three-shift workers in relation to psychological health and work-family conflict, Scand J Work Environ Health 30 (2) (2004), 149-156.

[72]F. Verdier, B. Barthe and Y. Queinnec, Organização do trabalho em shifts: concentrando-se na análise ergonômica ao longo das 24 horas. in: F.M. Fischer, C.R.C. Moreno, L. Rotemberg, eds, Trabalho em shifts e noshift, São Paulo, Atheneu, 2004, p.137-157.

[73] J. Walker, Social problems of shiftwork, in: S. Kolkart, T.H. Monk, eds Hours of work: temporal factors in workschedulling, Chichester, Wiley, 1985, p.211-225.

[74]A.A.I. Wedderburn, Guidelines for shiftworkers, European Foundation for the improvement of living and working conditions, Dublin, Loughlinstown House, 1991.

[75] A.A.I. Wedderburn, How fast should the night shift rotate? A Rejoinder, Ergonomics 35 (12/12) (1992), 1447-1452.

[76] R.T. Wilkinson, How fast should the night shift rotate? Ergonomics, 35(12/12) (1992),1425-1446. 